Narrative Works

Issues, Investigations, \& Interventions

\title{
Stories’ Work: Making Darkness Visible
}

\section{Arthur W. Frank}

Volume 9, Number 2, 2019

URI: https://id.erudit.org/iderudit/1076531ar

DOI: https://doi.org/10.7202/1076531ar

See table of contents

Publisher(s)

Centre for Interdisciplinary Research on Narrative, St. Thomas University

\section{ISSN}

1925-0622 (digital)

Explore this journal

Cite this review

Frank, A. (2019). Review of [Stories' Work: Making Darkness Visible]. Narrative Works, 9(2), 171-180. https://doi.org/10.7202/1076531ar 


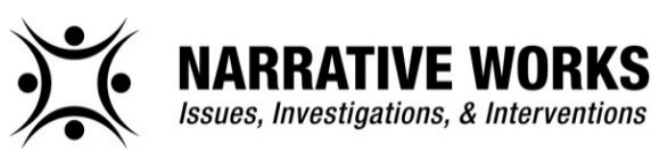

\section{BOOK REVIEW}

\section{Stories' Work: Making Darkness Visible}

Stephen Greenblatt, Tyrant: Shakespeare on Politics. New York, NY: Norton, 2018. Hardcover ISBN 978-0-393-63575-1.

Rhodri Lewis, Hamlet and the Vision of Darkness. Princeton, NJ: Princeton University Press, 2017. Hardcover ISBN 978-0-691-16684-1.

\section{Arthur W. Frank \\ University of Calgary}

Shakespeare provokes. The question of his place in cultural imaginations provokes intense discussion today, but my present concern is how his stories and his storytelling provoke, and thus how narratives work through provocation. These two books are both written to be provocative, although their respective provocations are diametrically different. Stephen Greenblatt simplifies Shakespeare's stories in order to provoke reflection on how the politics of tyranny in late sixteenth century England display fundamental mechanisms that remain visible in today's politics. Rhodri Lewis makes Hamlet more complicated by arguing that the play can be understood properly only in relation to philosophical texts of Renaissance humanism. Lewis provokes his readers to understand Hamlet to be a darker story in which the character of Hamlet is less a tragic hero than the focal point of a tragic situation.

As different as the books are in style and focus, they do have an eventual point of convergence. Both repay careful attention, not only for what they say but for how they say it. Lewis caused me considerably more struggle - and delay in writing this review - but his book makes the greater difference in how I think about Shakespeare specifically and about storytelling generally. 


\section{A Metanarrative of Tyranny's Rise and Fall}

Stephen Greenblatt is preeminent among contemporary Shakespeare scholars, known especially for Hamlet in Purgatory (2001). He begins that book with an historical anecdote about tyranny. In 1529, a London lawyer named Simon Fish published anonymously a tract directed to Henry VIII. Fish spoke for the wretched, the sick and homeless, presenting their plight as a result of the parasitic exploitation of national wealth by the clergy. Greenblatt paraphrases Fish's nonrhetorical question: "Why would otherwise sensible, decent people, alert to threats to their property, their health, and their liberties, allow themselves to be ruthlessly exploited by a pack of 'sturdy idle holy thieves'?" (p. 11). Greenblatt answers this question by turning to Fish's contemporary, Etienne de La Boétie, best known as the great friend of Montaigne. Seeking to explain what he called "voluntary servitude," La Boétie presented a structural explanation. "A chain of clientage extends and expands geometrically, he argues, from a small number of cynical exploiters at the top to the great mass of the exploited below. Anyone who challenges this system risks attack" (p. 12). Those who would resist "have no way of knowing who else among them has arrived at the same perception," so it is too dangerous to speak out. La Boétie's proposed response is "not a violent uprising but a quiet refusal" (p. 12).

Tyrant begins with a complementary question: "Under what circumstances, Shakespeare asked himself, do such cherished institutions, seemingly deep-rooted and impregnable, suddenly prove fragile? Why do large numbers of people knowingly accept being lied to? How does a figure like Richard III or Macbeth ascend to the throne?" (1). But times have changed since Hamlet in Purgatory. Greenblatt has changed, now seeking a broader, non-scholarly readership. American politics has also changed. Greenblatt begins his book's Acknowledgments by thanking a colleague who asked him what he was going to do about what was then the upcoming American presidential election of 2016. Tyrant is written in response to the question, "What can I do?" (p. 191). Put another way, the early Greenblatt wrote about power and politics in general terms; this time it's personal. Although the winner of that upcoming election is never named, he is clearly the tyrant about whom Greenblatt is trying to do something. That means enlisting Shakespeare's tyrants to provide a critique of the present tyrant. Some of those enlistments seem more successful than others. 
Greenblatt fashions a metanarrative of tyranny, and observing his craft in doing so makes it worth reading the book. He retells the stories of seven plays, including brief quotations of key lines, and weaves his commentary into the retelling without disrupting the storyline. Political critique blends into storytelling, making a smooth read. With each play, Greenblatt makes a point about tyranny. Thus the first play in the Henry VI trilogy, perhaps Shakespeare's earliest work, shows how "unwillingness to compromise" (p. 25) leads to party affiliations, the formation of which raises the anger level to rage (p. 27).

From the stories told in these seven plays, a core narrative emerges: the tyrant rises, often through crimes including betrayals of allies; once in power, his increasingly unsteady capacity to govern generates resistance that mobilizes; eventually, the tyrant's diminished capacities precipitate his fall. This narrative involves specific character types: the tyrant, his enablers, the "tools" who do the dirty work that includes killings, the victims (some more innocent, others more knowing), and resisters. Greenblatt is most interested in tyrants and enablers. The latter get their own chapter, in which subtypes are proposed: those who are genuinely fooled by the tyrant, those who are frightened, those who try to normalize the situation by denying how bad things are getting, those who trust institutions that prove too fragile in opposition, and those who think they can take advantage of the situation that the tyrant creates (pp. 66-68). These types seem real, but as an explanation for why people enable tyranny, they lack the subtlety of La Boétie on structural dilemmas of resistance to voluntary servitude. On tyrants themselves, Greenblatt is even more psychological in his explanations, emphasizing tyrants' narcissism. His writing has never seemed so psychoanalytic.

As much as I admire Greenblatt's skill in retelling Shakespeare's stories, my problem is that among the seven plays, I find only two genuine tyrants: Richard III and Macbeth. Here my reading of Greenblatt is influenced by Rhodri Lewis's (2018) review. I agree with Lewis that Greenblatt's most subtle analysis is not of a tyrant, but of Brutus in Julius Caesar, who resists what he imagines will become Caesar's future tyranny if Caesar is not stopped first. Most of those whom Greenblatt proposes as tyrants don't fit the role or the narrative. Lear begins the play by giving up power, albeit in a final act of kingship that seems less tyrannical than simply spiteful. Leontes in The Winter's Tale is driven by jealousy to a tyrannical moment, which he spends the rest of the play repenting. Coriolanus is offered political power, but instead of seizing it, 
he refuses to compromise his autocratic principles and ends up being banished. Macbeth does not show the narcissism that Greenblatt attributes to tyrants. Only Richard III is a clear example of a tyrant, and Greenblatt gives him the most sustained attention. But Greenblatt's metanarrative of tyranny may reduce even that play too far. ${ }^{1}$

Lewis's review objects to how Greenblatt, in order to present Richard as "a proxy for the moron elected to serve as the 45th president of the United States," is required to reduce Shakespeare's character: "Nothing of Richard's insights ... his intellect or clear-sighted appreciation of the way politics works ... of his courage ... of his charm." I abridge Lewis's considerable and true elaboration of Richard's attractions and competencies. Greenblatt has an excellent phrase for what's brilliant about Richard: "the ability to force his way into the minds of those around him" (p. 65). And those around him include the theatre audience, because we are talking here about Shakespeare's character. That character becoming unhinged is crucial to the Shakespearean drama, as it is to Greenblatt's metanarrative. "Once ruthlessly efficient, Richard begins to seem distracted," Greenblatt writes (p. 89). The narrative principle to which Richard must conform is that "the skills that enabled him [to ascend to the throne] are not at all the same as those required to govern successfully" (p. 87). ${ }^{2}$

Shakespeare's stories did the considerable work of expressing the political anxieties of their age from a perspective that, as Greenblatt notes, was sufficiently "oblique" (pp. 5, 184) to evade censorship, when censorship was rigorous and penalties harsh. The need for that work continues, and the plays continue to do that work. But however much I agree with Greenblatt that the present political moment requires thinking seriously about tyranny, explanations in Tyrant lack the subtlety of the opening of Hamlet in Purgatory. Tyrant reinforces my belief that stories

${ }^{1}$ A separate issue is whether Greenblatt can avoid how Shakespeare reduces the complexity of the historical Richard III to create the dramatic character that the play requires. Because Greenblatt wants his allegories of tyranny to have present day, realworld relevance, can he ignore how Shakespeare has changed history-or at least the discrepancy between history as we now believe it and as Shakespeare tells it? Greenblatt is creating a metanarrative to what is already an artistic metanarrative; that is, Shakespeare's creative vision of tyranny for dramatic purposes. I am genuinely undecided on this issue.

${ }^{2}$ On all of the historical accounts that I have read, Richard III governed as an excellent administrator, including the mobilization of his forces for the battle in which he died-a battle he came close to winning. That upsets both Shakespeare's drama and Greenblatt's metanarrative, raising the question of what work both narratives are intended to do. To what exactly are Shakespeare's plays a reliable guide? 
work better at reinforcing existing assent than at persuading those who disagree. Lewis's review of Tyrant goes further, describing the book's "complacent conviction that the reader will share Greenblatt's opinions of the current political situation, and that she will be glad to have these opinions buttressed by his account of Shakespeare's politics. No attempt is made to persuade. No attempt is made to establish a common ground with readers who might take a different view." I agree, but I question whether Lewis is asking Greenblatt's book to do work that stories are not best suited to do-and for most readers of this journal, that's the interesting question.

What's at stake here is how narratives work to political ends. Stories are unquestionably effective at buttressing views already held; notably, tyrants tell stories to solidify support. How well stories can persuade, whom they can persuade on what issues, is a crucial problematic for narrative research, very much the business of this journal. Tyrant may be most useful to narrative scholars for how it exposes the limits of using stories and narratives to polemic ends. That Greenblatt is as skilled as he is makes his book's limits all the more worth spending time considering.

\section{The Story Is Not the Character}

The story of the prince whose uncle kills the prince's father and marries his widowed mother, assuming the kingship that would have passed to the prince (Shakespeare, 2016), might be called a generative narrative. Innumerable stories are told within that recognizable narrative form. What's left to say about this most familiar of stories?

Rhodri Lewis's interpretation has drawn considerable criticism (for example, Gray, 2018). After praising Lewis's scholarship, the distinguished Shakespeare scholar James Shapiro (2018) concludes: "Lewis's Hamlet is not mine, nor is his Hamlet.... But I admire his relentless questioning of underexamined beliefs that have long guided our reading of Hamlet and, if he is right, have been instrumental in leading us into the political mire in which we now find ourselves" (p. 23). What is "Lewis's Hamlet" and more specifically, what work does Lewis argue Hamlet is doing, and what work does the character Hamlet do within the play?

If Greenblatt writes for a broad readership, Lewis writes for scholars. He connects aspects of Hamlet to so many early modern texts that I couldn't resist wondering whether Shakespeare or his audience 
could possibly have made all those connections. But the connections hold, whoever knew them however well, and they make an important point. The theatre director Dominic Dromgoole (2017), in one of my favourite cautions about Shakespeare, writes that: "Hamlet is not there to be the person we want him to be" (p. 261). If I understand Lewis, Hamlet's work is to upset our expectations for what we want him to be, or what someone in his situation could be. What I want Hamlet to be is the rightfully deserving object of Ophelia's praise-“ $\mathrm{O}$, what a noble mind is here o'thrown! The courtier's, soldier's, scholar's eye, tongue, sword" etc. (3.1.149-150) - and Horatio's epitaph: "Now cracks a noble heart. Goodnight, sweet Prince" (5.2.343). Audiences and readers want the sweet prince, as embodied by the star actor. Lewis shows that is not the character Shakespeare wrote.

I read Lewis as continuing, in a scholarly writing genre, the critical line set out by Jan Kott, one of the most influential Shakespeare critics of the 1960s. Kott (1966) argues that Shakespeare's tragedies represent the grotesque: "The tragic situation becomes grotesque when both alternatives of the choice imposed [on the hero] are absurd, irrelevant or compromising. The hero has to play, even if there is no game. Every move is bad, but... To throw down his cards would also be a bad move" (p. 135). He continues that in the tragi-grotesque, "the absolute has ceased to exist. It has been replaced by the absurdity of the human situation" (p. 137). ${ }^{3}$ Lewis does not cite Kott or many other contemporary critics, but when I ask Shapiro's question-what is "Lewis's Hamlet"? - Kott is my beginning of a response.

Lewis's introductory and concluding chapters present his dense, unified argument. Between are four substantive chapters: first, a consideration of the self as performance in Renaissance thought; next, a detailed unpacking of the allusions and metaphors of hunting in Hamlet. Lewis shows how much talk about hunting fills Hamlet. The relation between hunter and prey is the constant theme, and this chapter draws praise from even the harshest critics of the whole book. The following three chapters consider Hamlet's failures, at least his immaturity, as an historian remembering his father especially, as a poet, and as a philosopher. Lewis presses his case vehemently, and critics object to his

\footnotetext{
3 Relevant to Greenblatt's project, Kott (1966) presents an altogether different perspective: "Shakespeare does not distinguish between a good king and a tyrant, just as he does not distinguish between a king and a clown. They are both mortals. Terror and the struggle for power is not a privilege of princes; it is the law of this world" (p. 273). That sets up a far more complex narrative of tyranny.
} 
repeated deprecations of Hamlet in these chapters. I am willing to grant him his vehemence, because I so appreciate the Hamlet he argues for.

Lewis does not hate Hamlet, although his writing can sound that way. What he recognizes is Hamlet's inescapable place within Elsinore. If I understand correctly, the version of the play that Lewis might direct would be retitled Elsinore, because it is all about the milieu, and how each of the characters, especially Hamlet, reflects that milieu in his or her own respective way. The key to Hamlet is that he "must think and speak through that which he would disregard" (p. 11). "That" refers to his Wittenberg education specifically, but also Elsinore generally. Hamlet's "vision depends on the learned order he affects to despise" (p. 306). "He remains inescapably part of the order he appears to disdain - and offers the most vivid possible illustration of this order's shortcomings in his attempts to make sense of one's inner life" (p. 309). To me as a sociologist, this contextualizing assessment of Hamlet is predictable; to imagine anyone being otherwise is a fantasy. But that fantasy is the Hamlet whom, Dromgoole observes, people want him to be, the sweet prince who transcends his surroundings and effects a form of redemption.

What, then, is Elsinore, as the subject of the play? It is a place where "all are cut off from the resources through which they might understand themselves or make their existences meaningful" (p. 9); it provides "no discernible framework of right and wrong" (p. 10); and most lyrically: "Its moral universe is an unending night" (p. 10; see also pp. 307, 309). As a depiction of Elsinore, Hamlet offers "no realm of inner integrity or authenticity against which to measure the trifles, contingency, or mendaciousness of [anyone's] persona. Throughout, self-observation and self-examination are as untrustworthy and as dangerous as the public interactions that Hamlet so insistently disregards" (p. 31). In summary, "Shakespeare offers us nothing with which to mitigate Hamlet's existential struggles and evasions, or their tragic corollaries: they are of a piece with the moral dissonance that engulfs Elsinore as a whole" (p. 35).

There never can be any single, definitive understanding or stage production of Hamlet. Going back to Kott (1966): "One can perform only one of several Hamlets potentially existing within this arch-play" (p. 58). That said, Lewis's Hamlet, and his Hamlet, solve at least two problems that any interpretation must confront. Shakespeare positions the audience to be sympathetic to Hamlet, to anticipate that he will be the force that restores moral order after a terrible crime has disrupted that order. But then the problems occur: first, Hamlet's failure to make sense of the questions he poses, and second, his blindness to his own destructiveness. 
The sense-making problem is most evident in the play's most famous speech, the "To be or not to be" soliloquy.

My greatest single gratitude to Lewis is for liberating me from the need to understand "To be or not to be" as being about some central topic on which it reaches a conclusion. Lewis devotes an extended discussion to this speech, as any book on Hamlet must, and I will cut straight to his conclusion, which is stated in an unusually reserved tone: "I want to keep open the possibility that although the beginning of the fourth soliloquy sounds terrific, it designedly does not make sense" (p. 269). Having read whole books that attempt to make sense of the fourth soliloquy, I appreciate this recognition that Hamlet unquestionably sounds terrific, but he's not making sustained sense. What matters is that Hamlet, being part and parcel of Elsinore, cannot be expected to make sense. The work of the soliloquy is to show Elsinore to be a place without resources for making sense.

Lewis also frees interpretation from having to apologize for Hamlet's trail of destruction: his attack on Ophelia and partial responsibility for her subsequent madness, his unintended murder of Polonius, his arrangement for the execution of Rosencrantz and Guildenstern (who willingly served the king, but did not know they were escorting Hamlet to his execution), and his unconvincing apology to Laertes for killing his father, Polonius. There's a pattern to Hamlet's violences, which are more than a sequence of unfortunate events. These are not the acts of the person we want Hamlet to be, and recognizing how reluctant I am to give up the sweet Prince, I learn something about how easy it is to be one of the enablers whom Greenblatt describes.

Lewis, like Greenblatt, is fabricating a metanarrative. He goes about it very differently, amassing textual and historical details, but he too has political goals. Shapiro (2018) writes that "underexamined" views of Hamlet "have been instrumental in leading us into the political mire in which we now find ourselves." Unless we, readers and audience members, can recognize how Hamlet's "moral deliberations have stalled" (p. 274), then we cannot recognize the Elsinore of our own times. Lewis says a great deal about the moral condition known as Elsinore, perhaps most succinctly: "Truth is incidental" because "getting what one wants is the only criterion of success" (p. 278). Equally significant, Elsinore represents an insistence "on their own sufficiency" that impedes "the proper comprehension of the human lot" (309).

In my first reading of Lewis, I thought he failed to account for Hamlet's continuing attraction as a character, why Hamlet fascinates both 
actors and audiences. Lewis begins by rejecting the Romantic understanding of Hamlet as the "struggle of the modern subject to find a path through the thickets of moral, personal, and political existence" ( $p$. 2). But after more time with Lewis's book, I think he has given us an updated version of this struggle. Two points seem essential. First, Hamlet "only exists in relation to those on stage around him" (p. 8; emphasis added). To a sociologist, that observation is unremarkable, but stagings of Hamlet, especially emphasizing the soliloquies, can make us see him as exceptional, existing outside of and beyond his relationships. That way of thinking is crucial to apologies for Hamlet's violences. Stories that feature heroes make us forget that those heroes only exist in relation to those around them, just as any story only exists in relation to other stories around it. Again, the play is about Elsinore, and Hamlet serves as the limit-case of what Elsinore effects. Second in Lewis's updating of the subject's struggles, "there is a sense in which all those constrained to exist within the moral economy of Hamlet are interchangeable. All are bluffing their way through the dark" (p. 9).

Tyranny needs its Elsinore. Settings, maybe more than people, enable tyrants, who then shape settings. Here, Lewis's argument converges with Greenblatt's, and Lewis (p. 6) quotes Greenblatt's early writing to make his point that characters have their moral lives in community. Focus on the tyrant distracts from that communal focus. Greenblatt might have included Claudius among his pantheon of tyrants - he fits the metanarrative. He also might have included Hamlet, although that would have required writing much of Lewis's argument. Most of all, the truest tyrant may be Elsinore itself.

Lewis concludes by noting that, in the history of Hamlet's reception, "the irony is that its sublimity was held to inhere in the character of Hamlet, not in the totality of the play of which he is a part" (p. 314). Again, call the play Elsinore to emphasize the totality, of which the character is a part. Lewis frees us to appreciate Hamlet as the person we don't want him to be, but in whom we might better see ourselves and question what resources we have for making whatever sense we make, political or otherwise. He frees Hamlet to be a more relevant story for our times. The lessons for how students of any story can free that story to let it do its work are considerable. 


\section{References}

Dromgoole, D. (2017). Hamlet Globe to Globe. Grove Press.

Gray, P. (2018). Review of Rhodri Lewis, Hamlet and the vision of darkness. Review of English Studies, 69(292), 983-986.

Greenblatt, S. (2001). Hamlet in purgatory. Princeton University Press.

Kott, J. (1966). Shakespeare our contemporary. Anchor.

Lewis, R. (2018, June 24). Fashion it thus: Stephen Greenblatt's Tyrant. Los Angeles Review of Books. Retrieved from https://lareviewofbooks.org/article/fashion-itthus-stephen-greenblatts-tyrant/

Shakespeare, W. (2016). Hamlet. A. Thompson and N. Taylor (Eds.). Revised ed. Bloomsbury Arden Shakespeare.

Shapiro, J. (2018, April 19). The question of Hamlet. New York Review of Books, 20, 22-23. Retrieved from https:/www.nybooks.com/articles/2018/04/19/thequestion-of-hamlet/

Arthur W. Frank, PhD, is Professor Emeritus of Sociology at the University of Calgary, professor at VID Specialized University, Bergen, Norway, and core faculty at the Center for Narrative Practice in Boston. He is the author of a memoir of critical illness, At the Will of the Body (1991; new edition, 2002); a study of first-person illness narratives, The Wounded Storyteller (1995; expanded edition, 2013); a book on care as dialogue, The Renewal of Generosity: Illness, Medicine and How to Live (2004); and most recently, a book on how stories affect our lives, Letting Stories Breathe: A Socionarratology (2010). Dr. Frank is an elected Fellow of The Hastings Center and a Fellow of the Royal Society of Canada. He was the 2008 recipient of the Abbyann Lynch Medal for Bioethics, awarded by the Royal Society of Canada, and the 2016 recipient of a Lifetime Achievement Award from the Canadian Bioethics Society. 